Volume 13 Number 1, January-March 2019: pp. 31-42. Copyright (c) 2019 FIAT JUSTISIA. Faculty of Law, Lampung University, Bandarlampung, Lampung, Indonesia. ISSN: 1978-5186 | e-ISSN: 2477-6238.

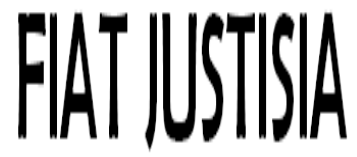

Fiat Justisia is licensed under a Creative Commons Attribution 4.0 International License, which permits unrestricted use, distribution, and reproduction in any medium, provided the original work is properly cited.

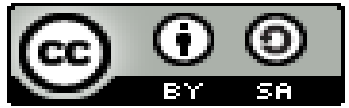

\title{
Problematics in Handling Criminal Offence on Poor Communities by Advocate (A Study on Gunung Sugih District Court)
}

\author{
Marwan Jaya Saputra \\ Prosecuting Counsel's Office of Gunung Sugih District, Indonesia \\ marwanjayaputra@gmail.com
}

\begin{abstract}
The provision of legal aid to the poor is one of the actions of the noble profession of advocates and the moral movement that advocates for human rights, in fact, not all advocates are morally aware of their obligations. There are still many deviations found in the provision of legal aid for the poor. This condition is certainly contrary to the noble values of the advocate profession itself, in the presence of this matter, which shows still can be found deviations in practice. The problem examined in this study is why law enforcers such as judges and posbakum have not provided free legal assistance to the poor in Central Lampung Regency, a factor that has caused law enforcement agencies not to offer and provide free legal assistance to the poor and the pattern / model of handling criminal cases against the poor by advocates based on justice. The method used in this research is with socio-legal research approach that comes from collecting data obtained from primary data and secondary data, then analysed by qualitative analysis method.

The results of this study ultimately provide an answer that Advocates who have not yet applied the value of justice in handling criminal cases involving the poor are due to legal substance, legal structure, and legal culture, Not yet applying the value of justice in handling criminal cases against the poor is like the emergence of mistrust of the law, besides the model of handling criminal cases against the poor by advocates based on the value of justice is the implementation of constructive strategies, such as: Legislation Planning, Policies and Activities Related to the Fulfilling Right to Legal Assistance. Suggestions from this research are to Advocates regarding Integrity, morality, idealism, and professionalism of law enforcement officers
\end{abstract}


should be further enhanced, in addition to the restrictions on the provision of legal aid in LBH should also be reviewed to enforce the principle of providing legal assistance as widely and equality before the law.

Keywords: Criminal Case, Poor People, Advocates and Justice Values

How to Cite: Marwan Jaya Saputra, "Problematics in Handling Criminal Offence on Poor Communities by Advocate (A Study on Gunung Sugih District Court)", Fiat Justisia, 13 (1), (2019).

DOI: https://doi.org/10.25041/fiatjustisia.v13no1.1406

\section{A. Introduction}

Legal assistance is one of the rights of every individual to defend rights from the level of investigation to the trial process. For people who cannot afford it is the duty of the State to provide legal assistance. Provision of legal aid funds by the government is an embodiment of the government's efforts to enforce the law in the context of equal opportunity to obtain justice within the legal state of the Republic of Indonesia, ${ }^{1}$ therefore someone who is accused of a crime if someone is offered a defense because according to the Panel of Judges and KUHAP someone who is a defense attorney comes from the government (legal aid fund), for that it is also expected that both lawyers and the Legal Aid Institute (LBH) can participate in this government business, even though with minimal funds according to the country's financial capacity. ${ }^{2}$

Providing legal assistance to the poor is an implementation effort of a state law that recognises, guarantees, and protects human rights. Legal assistance is also given as an effort to fulfil the need for access to justice and equality before the law (equality before the law). In implementing legal assistance, advocates as people who provide legal assistance certainly have a very large obligation and role in this matter. Ropaun Rambe stated that the advocate profession is known as the noble profession (officium nobile) because it requires the defense to all people regardless of their race, colour, religion, culture, socio-economic background, rich in poor, political beliefs, gender, and ideology. Ropaun Rambe also stated that: Advocate profession is a respectable profession because of the professionalism in it. Also, the advocate profession is not solely for earning a living, but in it, there is an

\footnotetext{
${ }^{1}$ AR. Arif, "Pelaksanaan Pemberian Bantuan Hukum Terhadap Terdakwa yang Tidak Mampu dalam Perkara Pidana di Kota Bandar Lampung," Fiat Justisia, Vol.9 No.1, (2015), p.7.

${ }^{2}$ R. Muklis, "Optimalisasi Peran dan Fungsi Advokat dalam Sistem Peradilan Pidana sebagai Salah Satu Uapaya Peningkatan Kesejahteraan Masyarakat", Jurnal Ilmu Hukum Riau, Vol.2 No.1, (2011), p.4.
} 
idealism (such as the value of justice and truth) and morality that is highly upheld.

By the noble profession (officium nobile), advocates must defend their communities and clients without discrimination and differentiation of treatment by the principle of equality before the law. Advocates have an important position as a pillar in law enforcement, in upholding Human Rights, and have a control function to keep the court clean, honest and fair. Advocates in the criminal justice system are also part or sub-system of criminal justice and are also law enforcers. Advocates have an important role in criminal justice. Ropaun Rambe also stated that the advocate profession is a respectable profession. However, the current condition of the advocate profession is quite alarming because of the occurrence of irregularities. Advocates now play more roles as case brokers. This condition is certainly a serious problem, which is now being faced by the criminal justice system in Indonesia. Now advocates have experienced a shift in value. At present, the advocate profession is often considered to be no longer a noble profession that stands for truth and justice. Individual advocates who defend their clients in all ways to achieve victory by bribery, the disappearance of evidence, and other negative ways, certainly lead to various assumptions towards pessimism and scepticism about law enforcement in Indonesia. Advocates are often regarded as judicial mafia or case brokers, which of course undermines the image of the noble advocate's profession.

Deviations and shifts in serious problems, however, amid pessimism and scepticism towards advocates. Acts of deviation committed by individual lawyers who damage the image of the current advocate profession should not be a barrier to implementation of the noble profession. It should be realized that providing legal assistance to people or groups of poor people is one form of action from a very noble profession and a moral movement that fights for human rights.

Not all advocates are morally aware of these obligations. There are still many deviations found in the provision of legal assistance to people or groups of poor people. This condition certainly contradicts the noble values of the advocate profession itself, with this, which shows that deviations can still be found in practice, it is necessary to review the development of the implementation of legal assistance in Indonesia, especially for the poor involved in criminal cases.

\section{B. Research Method}

This research is a socio-legal approach. The socio-legal approach is used to analyse various laws and regulations and advocacy laws for the poor. Meanwhile, the socio-legal research approach is research that refers to legal norms and principles contained in legislation and court decisions/facts in the 
field. Ronald Dworkin called the research method also doctrinal research, which is a study that analyses both laws as it is written in the book, as well as law as a law that is decided by the judge through the judicial process. ${ }^{3}$

Three reasons for using qualitative, empirical legal research. First, qualitative analysis is based on the paradigm of the dynamic relationship between theory, concepts and data which is constant feedback or modification of theories and concepts based on those collected. Second, the data to be analysed in a variety of ways, has basic characteristics that differ from one another, and is not easy to quantify. Third, the basic nature of the data to be analysed in research is comprehensive and is an integral unit, where it shows the diversity of data and requires deep information (independent information). ${ }^{4}$

The three qualitative research criteria are contained in this thesis research, so it is reasonable to use qualitative methods in data analysis. This research is comprehensive because it seeks to explore the whole. This study also seeks to find a harmonious relationship from the concepts found in primary and secondary legal materials using theories or legal doctrines, ${ }^{5}$ related to the problems in handling criminal cases against the poor by advocates.

\section{Discussion}

\section{Law Enforcement as Judges and Posbakum do not Give Free Legal Aid to the Poor}

Many problems have hampered the implementation and development of legal assistance so that the value of justice has not been realised in handling criminal cases involving the poor, as explained in a number of them below:

\section{a. Absence of Important Information Related to Legal Aid}

Legal assistance is a reflection of the human rights movement. As a community movement, sufficient information is needed and carried out at the grassroots level. ${ }^{6}$ Legal assistance will only be effective in reaching the target of the poor and marginalized groups if it is based on the availability of the following information: (i) information on the number of poor justice seekers;

\footnotetext{
${ }^{3}$ Anselmus Strauss, and Juliat Corbin, Basic of Qualitative Research, Grounded Theory Procedure and Technique, Newbury, Park London, New Delhi: Sage Publication, (1979), p.7. ${ }^{4}$ William J. Filstead, Qualitative Methods : A Needed Perspective in Evaluation Reseaarch, dalam Thomas D. Cook dan Charles S. Reichardt, ed, Qualitative and Quantitative Methods in Evalution Research, London: Sage Publications, (1979), p. 38.

${ }^{5}$ Chai Podhisita, et al, Theoritical Terminological, and Philosophical Issues in Qualitative Research, Qualitative Research Methods, p. 7.

${ }^{6}$ Abdurrahman, Aspek-Aspek Bantuan Hukum di Indonesia, Jakarta: Cendana Press, (1983)
} 
(ii) the amount of the budget allocated for free legal assistance and the amount that is truly accessible to justice seekers; (iii) the number of legal aid providers that actually provide free legal assistance; and (iv) the number of lawyers who provide free legal assistance in judicial bodies. ${ }^{7}$

\section{b. Prerequisites for Building Community Trust}

There are at least six conditions in the western justice system that make citizens want and believe this system can provide justice. The six conditions are as follows: (i) the professionalism of law enforcement officers ${ }^{8}$ (ii) the existence of an integrated information system that can be easily accessed by the community; (iii) transparency in the body of law enforcement institutions; (iv) law enforcement officers carry out authority and service to the community responsibly; (v) placing law enforcement officers in a noble profession; and (vi) the existence of professional protection and incentives for law enforcers. In Indonesia, the things mentioned above have not been fully realised. Law enforcement officials are often reduced and reduce themselves to become tools of power. In this situation, legal assistance faces difficulties in helping poor and marginalised people obtain justice from the formal justice system. Public trust in the legal system and law enforcement officials has a close relationship with the practice and implementation of legal assistance in Indonesia. Groups of poor and marginalised people in the practice of avoiding and fearing using legal mechanisms, especially fighting for justice through the judiciary, because they often become victims of the practice of the judicial mafia.

\section{c. Low Level of Government Political Sensitivity}

This is a common problem that exists in governments in developing countries. When the public expresses criticism, aspirations or complaints about injustices, laws that are favouritism and indiscriminate and arbitrary, the government does not attempt to improve and increase public trust in the system and the judicial institution. Although there is some evidence that shows that the government has encouraged the fulfilment of the rights of citizens and communities, including economic, social and cultural rights, which can help the realisation of social capital of the community. Likewise, the government's obligation to facilitate and allocate funds for improving and expanding access to justice for the community needs to be improved.

\footnotetext{
${ }^{7}$ Agustinus edy Kristanto \& Patra M. Zein, Panduan Bantuan Hukum di Indonesia, p. 36. (Pedoman Anda Memahami dan Menyelesaikan Masalah Hukum), Jakarta: YLBHI, (2008), p. 98.

${ }^{8}$ Bambang Sunggono dan Aries Harianto, Bantuan Hukum dan Hak Asasi Manusia, Bandung: Mandar Maju, (1994), p. 67.
} 


\section{d. Political Will of Decision Makers}

The rule of law and respect for the rights of all people in western countries are not without challenges. ${ }^{9}$ However, it can be realised because of systematic and serious efforts, led by people who devote their attention, including philosophers and academics, who pay attention to the realisation of the right to legal assistance. Legal reform programs and reform of law enforcement institutions currently swallow millions of US dollars, such as the prosecutor's reform program, grand court renewal, reform of police institutions, including improving case management, training and so on. But without the firmness and strong will of each institution leader, such programs will not have much impact on increasing access to justice for the community. Likewise in the right to legal assistance, without the political will of decisionmakers, the fulfilment of this right will be difficult to realise. For example, until now there has not been published a Legal Aid Act that is pro-poor and marginalised. ${ }^{10}$

\section{e. Unsuccessful Legal Reform}

Many efforts have been made, but legal reforms are still struggling, and problems are still piled up. Why are legal reforms that have been implemented or those that are running unsatisfactorily? The scarcity of a firm, hard and courageous figure is therefore sought after as the leader of a judicial, prosecutorial, advocate and police institution as well as community leaders who can be role models. ${ }^{11}$ Increasing the trust of the poor towards law and justice is related to the presence or absence of empowerment of legal rights to fulfil justice for them. Of course, to make this happen a figure who has a strong, firm and brave commitment is needed. In other words, leaders who side with the poor.

Continuing the 5 (five) points described above, related to the community in Central Lampung Regency not yet receiving fair-based legal assistance, Widodo straightforwardly stressed that the factors that hampered the implementation of legal assistance and the failure to achieve the value of justice were the hopes of the poor in particular. includes many factors, among others, due to the still difficult access to legal assistance for the people of Central Lampung Regency, because there is still a lack of knowledge about legal assistance so that in this case the poor who are involved in legal issues

\footnotetext{
${ }^{9}$ Binziad Kadafi, dkk, Advokat Indonesia Mencari Legitimasi; Studi Tentang Tanggung Jawab Profesi Hukum di Indonesia, Jakarta: Pusat Studi Hukum \& Kebijakan Indonesia, (2001), p. 77.

${ }^{10}$ Suteki, Hukum dan Alih Teknologi: Suatu Tinjauan Sosiologis, Jogjakarta: Thafa Media, (2013), p. 156.

11 Adnan Buyung Nasution, Bantuan Hukum di Indonesia, Jakarta: Lembaga Penelitian, Pendidikan, dan Penerangan Ekonomi dan Sosial, LP3ES, (1982), p. 9.
} 
are more likely to surrender and not report, then regarding the number of legal aid officers also very influential because of the lack of numbers of staff resulting in many cases that are less effective to deal with and the impact of not creating the value of justice for the community.

Complementing Widodo's statement, Deddy Waloyo also added information about the fact that the value of justice was not yet realized in providing legal assistance to the poor, according to Deddy Waluyo's statement that the Government's budget for advocates working in legal aid institutions has not flowed or has not been implemented properly, so that it has an impact on the total and effective paralegals and Advocates in providing legal assistance to the poor involved in criminal cases.

\section{Pattern and Model of Criminal Case Handling of the Poor by Advocates Based on Justice Value}

The poor and marginalised need legal development that can balance the functions of the law as providers of justice and benefits other than certainty. To go in that direction, within the next five years, reforms in the field of law and justice need to be carried out which include: ${ }^{12}$ (i) paradigm changes and the direction of legal development that can balance the functions of certainty, justice and legal benefit for the community; (ii) improvement of the legal formation process towards a process that is able to actively involve the community in the formation of legislation; (iii) comprehensive improvement of the performance of law enforcement agencies in order to be able to provide access for the poor and marginalized in obtaining substantial justice and obtaining recovery from their basic rights violated by the state and community groups and citizens of other countries; and (iv) legal empowerment for the poor and marginalized groups.

Based on that, in an effort to realize the patterns and models handling the criminal case against the poor in order to change the views of the poor to advocate for a more positive direction that upholds the values of justice and advocate the integrated well in Central Lampung regency in particular, Reza then terminate that do strategy- strategy constructive, namely as:

\section{a. Strategy for Fulfilling the Right to Legal Aid}

1) Fulfillment of the right to legal assistance.

Legal assistance has two main functions: (1) providing protection and fulfilment of everyone's equality before the law, including realising fair trials;

${ }^{12}$ Adnan Buyung Nasution, Desain Hukum di Ruang Sosial, Bantul Yogyakarta-Semarang: Thafa Media dan Satjipto Rahardjo Institute, (2013), p. 194. 
(2) promoting and contributing to the government's social welfare agenda and state development programs, such as programs to improve labour/labour welfare, entrepreneurship and ownership.

2) I realize the equality of everyone before the law.

Considering that the number of poor people in Indonesia is still very large, the APBN and APBD allocations for aid programs need to prioritize legal aid funding, as follows: (i) ensuring that every poor person is accompanied by an advocate to get a fair trial; (ii) Allocation of funds is enjoyed by people or groups of people who are socially marginalized, where they without legal assistance cannot enjoy fair trial and other human rights; and (iii) contribute to the defense of the poor to obtain basic rights, such as the right to work, land rights, rights to water, the right to health and the right to education.

3) I realize a fair and effective justice system.

The Legal Aid Program will: (i) protect the rights of the poor, innocent, vulnerable and marginalized; (ii) ensuring assistance and advocacy for poor people; (iii) the balance of support including the allocation of state funds to judges, police and prosecutors; and (iv) balance the allocation of state funds to the Supreme Court, Attorney General's Office, National Police with legal aid agencies and advocate organizations.

4) Promote the improvement of the quality of legal aid services for the poor.

The legal aid program will realize: (i) competitive and active legal services and services by providing remuneration for public advocates and practitioners; (ii) ensuring that all advocates and practitioners who provide legal services to the public are unable to obtain proper remuneration; and (iii) encourage the implementation of the responsibilities of the advocate profession and legal practitioners. ${ }^{13}$

5) Resolve legal issues faster and prevent social conflicts.

Effective legal assistance will contribute to the effective resolution of legal disputes and problems, which directly and indirectly minimise serious social impacts, social exclusion. The legal problems of the poor who are not quickly resolved will stop and limit the opportunities and opportunities that should be enjoyed and available to everyone in the community. ${ }^{14}$

${ }^{13}$ MM. Rozi, "Peranan Advokat Penegak Hukum dalam Sistem Peradilan Pidana Dikaji Menurut Undang-Undang Nomor 18 Tahun 2003 tentang Advokat", Jurnal Mimbar Justitia, Vol.7 No.2, (2015), p.8.

${ }^{14}$ A. Raharjo, "Mediasi sebagai Basis dalam Penyelesaian Perkara Pidana," Mimbar Hukum Universitas Gajah Mada, Vol 20 No 1, (2008), p. 6. 
The government can promote conflict resolution effectively and immediately through legal aid programs, with the aim of (i) reducing the number of direct and immediate legal cases and conflict disputes to the person concerned; (ii) facilitating the processing of services and the initial level, thus preventing and developing becoming more serious and expensive (more serious and costly); (iii) focus on groups of people who really need it, namely workers, farmers, urban poor groups, indigenous people, and groups of women and children.

b. Legislation, Policy and Activities related to the Fulfillment of the Right to Legal Aid

This strategy is realised through the preparation of a comprehensive development plan regarding community rights to legal assistance. This strategy aims to create a common perception of all development actors, especially to realise the right to legal assistance, with basic principles and principles: the community is positioned as the subject of the development program, not merely being the object of the program that will be planned and implemented. In this context, community participation in development programs should be 'full and meaningful' ${ }^{15}$, so that the marginalised community truly feels the benefits of the development program. In other words, development programs should provide optimal space for the participation of the poor and marginalised so that they feel the benefits of the development program.

\section{Conclusion}

1. Law enforcers such as judges and posbakum have not provided free legal assistance to the poor because of 3 factors, namely legal substance, legal structure, and legal culture. ${ }^{16}$ The legal substance factor that has not yet realised the value of justice is one of the shortcomings or weaknesses in the substance of Article 56 paragraph (1) of the Criminal Procedure Code which regulates the limitation of recipients of legal assistance based on the quality of the threat of punishment. Factors of legal structure that have not yet realised the value of justice, namely, law enforcement factors from internal and external aspects which also include facilities or facilities. Factors of law enforcers in terms of internal values that apply justice, such as lack of integrity, morality, idealism and professionalism of advocates. ${ }^{17}$ External law enforcement factors and facilities or facilities that hamper

\footnotetext{
${ }^{15}$ Bambang Sunggono dan Aries Harianto, Bantuan Hukum dan Hak Asasi Manusia, Bandung: Mandar Maju, (1994), p. 43.

${ }^{16}$ Burhan Ashshofa, Metode Penelitian Hukum, Jakarta: Rineka Cipta, (2010), p. 14.

${ }^{17}$ F. Rompies, "Kewenangan Advokat Didalam Sistem Peradilan Pidana Guna Menunjang Sistem Peradilan Terpadu," Lex et Societatis, Vol 1, No 2 (2013), p. 8.
} 
such as lack of funding or budget, lack of control and supervision, mechanisms and systems for obtaining a complicated budget that LBH must pass. The legal culture factor that has not yet manifested the value of justice by advocates to the poor includes legal, cultural factors or cultural factors and community factors. Factors in legal or cultural culture, in this case, include legal or cultural factors from the community and law enforcement (investigators and advocates). Like, the lack of public understanding of the right to legal assistance refers to distrust, pessimism, and scepticism about the implementation of legal assistance, and elements of attitudes, values, ways of acting and thinking of advocates and investigators, which occur repeatedly so that it leads to deviations or actions. Community factors include negative community views about the implementation of legal assistance and concerns in using legal assistance.

2. The pattern/model of handling criminal cases against the poor by advocates based on justice is by implementing constructive strategies, namely: Legislation Planning, Policies and Activities related to Fulfillment of the Right to Legal Aid. This strategy is realised through the preparation of a comprehensive development plan regarding community rights to legal assistance. This strategy aims to create a common perception of all development actors, especially to realise the right to legal assistance, with basic principles and principles, the community is positioned as the subject of the development program, not merely being the object of the program that will be planned and implemented. In this context, community participation in development programs should be full and meaningful, so that marginalised communities truly feel the benefits of development programs. In other words, development programs should provide optimal space for the participation of the poor and marginalised so that they feel the benefits of the development program. The specifications of the model are as follows: (1) Establishment of legal instruments that guarantee access of the poor to obtain legal assistance, (2) Development of institutional capacity and legal resources, (3) Development of funding for the development of access to legal assistance, (4) Regional development, (5) Development of legal education that supports the implementation of legal assistance, and (6) Providing awards for legal aid servants

\section{Acknowledgements}

Advocates who handle criminal cases involving the poor so that the suspect can enjoy legal assistance through advocacy assistance at the initial stage, not at the time of additional examinations and the examination should not be carried out before the presence of an advocate. Integrity, morality, 
idealism, and professionalism of law enforcement officers must be further enhanced. There is a need to provide provisions to provide legal assistance to suspects and defendants who are suspected and charged with committing criminal offences with a criminal penalty under 5 (five) years. The restrictions on the provision of legal assistance in LBH must also be reviewed to uphold the principle of providing the widest range of legal assistance (access to legal counsel) and principles of equality before the law.

\section{A. Books}

\section{Bibliography}

Abdurrahman. Aspek-Aspek Bantuan Hukum di Indonesia. Jakarta: Cendana Press.

Agustinus edy Kristanto \& Patra M. Zein. (2008). Panduan Bantuan Hukum di Indonesia (Pedoman Anda Memahami dan Menyelesaikan Masalah Hukum). Jakarta: YLBHI.

Anselmus Strauss, and Juliat Corbin. (1979). Basic of Qualitative Research, Grounded Theory Procedure and Technique. Newbury, Park London, New Delhi: Sage Publication.

Ashshofa, Burhan. (2010). Metode Penelitian Hukum. Jakarta: Rineka Cipta Bambang Sunggono dan Aries Harianto. (1994). Bantuan Hukum dan Hak Asasi Manusia. Bandung: Mandar Maju.

Filstead, William J. (1979). Qualitative Methods: A Needed Perspective in Evaluation Research, Dalam Thomas D. Cook dan Charles S. Reichardt, ed, Qualitative and Quantitative Methods in Evaluation Research. London: Sage Publications.

Kadafi, Binziad. (2001). Advokat Indonesia Mencari Legitimasi; Studi Tentang Tanggung Jawab Profesi Hukum di Indonesia. Jakarta: Pusat Studi Hukum \& Kebijakan Indonesia.

Nasution, Adnan Buyung. (1982). Bantuan Hukum di Indonesia. Jakarta: Lembaga Penelitian, Pendidikan, dan Penerangan Ekonomi dan Sosial (LP3ES).

Podhisita, Chai. (1983). Theoretical Terminological, and Philosophical Issues in Qualitative Research. Qualitative Research Methods

Suteki. (2013). Desain Hukum di Ruang Social. Bantul YogyakartaSemarang: Thafa Media dan Satjipto Rahardjo Institute.

Suteki. (2013). Hukum dan Alih Teknologi: Suatu Tinjauan Sosiologis. Jogjakarta: Thafa Media.

Waluyo, Bambang. (1991). Penelitian Hukum Dalam Praktek. Jakarta: Sinar Grafika.

\section{B. Journals}


AR. Arif, "Pelaksanaan Pemberian Bantuan Hukum Terhadap Terdakwa yang Tidak Mampu dalam Perkara Pidana di Kota Bandar Lampung", Fiat Justisia, Vol.9 No.1, (2015). https://doi.org/10.25041/fiatjustisia.v9no1.591 .

MM. Rozi,“ Peranan advokat penegak hukum dalam sistem Peradilan pidana dikaji menurut undang-undang Nomor 18 tahun 2003 tentang advokat", Jurnal Mimbar Justitia, Vol.7 No.2, (2015).

R. Muklis, "Optimalisasi Peran dan Fungsi Advokat dalam Sistem Peradilan Pidana sebagai Salah Satu Uapaya Peningkatan Kesejahteraan Masyarakat", Jurnal Ilmu Hukum Riau, Vol.2 No.1, (2011).

A. Raharjo, "Mediasi sebagai Basis dalam Penyelesaian Perkara Pidana", Mimbar Hukum Universitas Gajah Mada, Vol 20 No 1, (2008).

E. Rompies, "Kewenangan Advokat Didalam Sistem Peradilan Pidana Guna Menunjang Sistem Peradilan Terpadu", Lex et Societatis, Vol 1, No 2 (2013). 